www.jmscr.igmpublication.org

Impact Factor (SJIF): 6.379

Index Copernicus Value: 79.54

ISSN (e)-2347-176x ISSN (p) 2455-0450

crossrefDOI: https://dx.doi.org/10.18535/jmscr/v6i8.175

Journal Of Medical Science And Clinical Research

IGM Publication

An Official Publication of IGM Publication

\title{
Study of lipid peroxide levels and status of antioxidant enzymes in alcoholic hepatitis patients
}

\author{
Authors \\ Sanjay Bhatt ${ }^{1 *}$, M. Itagappa ${ }^{2}$, J. B.Gogoi ${ }^{3}$ \\ ${ }^{1}$ Ph.D. Scholar, Department of Biochemistry, Santosh Medical College \& Hospital, Santosh University, \\ Ghaziabad, UP \\ ${ }^{2}$ Department of Biochemistry, Santosh medical college \& Hospital, Santosh University, Ghaziabad, UP \\ ${ }^{3}$ Department of Biochemistry, V.C.S.G.G.I.M.S \& R Srinagar Garhwal, Uttarakhand \\ *Corresponding Author \\ Sanjay Bhatt, Ph.D. Scholar \\ Santosh Medical College \& Hospital, Santosh University, Ghaziabad, UP, India
}

\begin{abstract}
Background: The real status of pro-oxidant and antioxidant in alcoholic hepatitis is still not clear.

Material \& Methods: This study was conducted in Department of Biochemistry, Santosh medical college \& Hospital. 40 alcoholic hepatitis patients were subjected to detailed clinical examination and laboratory investigations and the results were compared with 40 controls. Blood samples were collected for oxidative stress parameters. It was observed that there was a significant increase in activities of SOD, MDA and Catalase activity in patients with alcoholic hepatitis when compared to controls.

Results: Result of this study depict higher oxygen free radical production, evidenced by elevated levels of MDA and decreased levels of Catalase activity, supporting the evidence of oxidative stress in alcoholic hepatitis patients. Increased activities of antioxidant enzymes might be a compensatory regulation of body in response to increased oxidative stress.

Conclusion: Data of this study represent that antioxidant defense mechanisms might be impaired in patients with alcoholic hepatitis. These findings also provide a theoretical basis for development of novel therapeutic strategies, such as antioxidant supplementation.
\end{abstract}

Keywords: Superoxide dismutase (SOD), Catalase, Alcoholic Hepatitis (AH).

\section{Introduction}

A subset of patients with ALD will develop severe alcoholic hepatitis (AH), which has a substantially worse short-term prognosis. ${ }^{1} \mathrm{AH}$ also represents a spectrum of disease, ranging from mild injury to severe, life-threatening injury, and often presents acutely against a background of chronic liver disease. ${ }^{2,3}$ The true prevalence is unknown, but histologic studies of patients with ALD suggest that $\mathrm{AH}$ may be present in as many as $10 \%-35 \%$ of hospitalized alcoholic patients. ${ }^{4-5}$. The disease is often progressive and is considered to be a major cause of morbidity and mortality. In recent years, oxidative stress has been implicated in the path physiology of a large number of disease or disorders which are initiated and /or exacerbated by pro-oxidants such as various drugs including alcohol and food additives. Besides, ingested 
alcohol produces striking metabolic imbalances in the liver. It leads to the formation of reactive oxygen species (ROS). Inadequate removal of ROS may cause cell damage by attacking membrane lipids, proteins and inactivating enzymes thus mediating several forms of tissue damage. At present, except for the abstinence of alcohol abuse, there is no effective modality of either prevention or treatment. The incidence of Alcohol Hepatitis is increasing day by day specially in the developing countries including India. This study was planned with the objectives to investigate the oxidative damage and the efficiency of antioxidant defense system in patients of alcoholic hepatitis in the socioeconomic belt of Srinagar, Garhwal, Uttarakhand.

\section{Materials and Methods}

Fourty clinically, pathologically proven fresh cases of alcoholic hepatitis (group A; age: 21-45 years) and fourty clinically healthy volunteers of either sex (group B; age: 17-40 years) were included in this study. Only minimal and moderately advanced patients of alcoholic hepatitis were included in the present study. All subjects took their usual (although not identical) meals three times daily; breakfast around 8:30 a.m., lunch around 13:30 p.m. and dinner around 20:30 p.m., without any change in their usual fluid intake. The burden of environmental temperature and pollution, if any, was common to all participants. Prior to the blood sample collection, the participants refrain from taking any drugs/preparation that would affect or alter the oxidative stress, its defensive mechanism, level and rhythm. Six millilitres of blood was collected from each subject at fixed time in plain and sterile vials containing heparin as anticoagulant. The plasma was separated and analyzed for lipid peroxides in terms of malondialdehyde (MDA) ${ }^{(7)}$. The haemolysate was prepared from the red cells and used for the measurement of the activities of enzymes superoxide dismutase (SOD), catalase $(\mathrm{CAT})^{(8,9,)}$.

\section{Results \& Observations}

Table-1 Distribution of patients of Alcoholc hepatitis according to groups

\begin{tabular}{|l|c|}
\hline Group & Number of Participants \\
\hline A & 40 \\
B & 40 \\
\hline Total & 80 \\
\hline
\end{tabular}

Table-2 Serum Superoxide Dismutase (SOD), Malondialdehyde (MDA), and Catalase levels amongst normal healthy individuals and patients of alcoholic hepatitis

\begin{tabular}{|l|c|c|}
\hline Parameters & Control $(\mathrm{n}=40)$ & Patients $(\mathrm{n}=40)$ \\
\hline SOD & $21.91 \pm 0.05$ & $17.05 \pm 0.09$ \\
MDA & $2.50 \pm 0.03$ & $3.05 \pm 0.03$ \\
Catalase & $16.55 \pm 0.04$ & $13.18 \pm 0.08$ \\
\hline $\boldsymbol{*} \mathbf{P}<\mathbf{0 . 0 0 1}$
\end{tabular}

\section{Discussion}

These data reveal that antioxidant defense mechanisms might be impaired in patients with alcoholic hepatitis. These findings also provide a theoretical basis for development of novel therapeutic strategies, such as antioxidant supplementation.

A marked plasma MDA level was recorded in healthy Indians and alcoholic hepatitis patients. The plasma MDA levels elevated in patients in comparison to healthy controls. There are no reports regarding circulating lipid peroxides in alcoholic hepatitis patients under tropical conditions. A statistically significant status was recorded in SOD, CAT concentrations in clinically healthy subjects and alcoholic hepatitis patients. SOD activity was found to be maximum in patients. Moreover, the activity was noticed to be decreased at all sampling hours during a 24hour sleep-awake period in patients in comparison to their healthy counterparts. The CAT activity was also noticed to be reduced in patients. The decreased concentration of measured antioxidant enzymes in alcoholic hepatitis patients could probably be associated with oxidative stress and/or decreased antioxidant defense mechanism. clearly exhibited an imbalance between oxidant and antioxidant defensive systems in the human body under such pathological situations. 


\section{References}

1. Orrego H, Blake JE, Blendis LM, Medline A. Prognosis of alcoholic cirrhosis in the presence and absence of alcoholic hepatitis. Gastroenterology 1987;92:208214.

2. Alcoholic liver disease: morphological manifestations. Review by an international group. Lancet 1981;1:707-711.

3. Ishak KG, Zimmerman HJ, Ray MB. Alcoholic liver disease: pathologic, pathogenetic and clinical aspects. Alcohol Clin Exp Res 1991;15:45-66.

4. Christoffersen P, Nielsen K. Histological changes in human liver biopsies from chronic alcoholics. Acta Pathol Microbiol Scand A 1972;80:557- 565.

5. Mendenhall CL. Alcoholic hepatitis. Clin Gastroenterol 1981;10:417-441.

6. Trabut JB, Plat A, Thepot V, Fontaine H, Vallet-Pichard A, Nalpas B, et al. Influence of liver biopsy on abstinence in alcohol-dependent patients. Alcohol Alcohol 2008;43:559-563.

7. Ohkawa H, Ohishi N, Yagi K. Assay for lipid peroxidesin animal ssue by thiobarbituric acid reac on. Anal. Biochem. 1979;95: 351-358.

8. McCord JM, Fridovich I. Superoxide dismutase: an enzyme func ons for erythrocuprin. J. Biolchem. 1969;24:6049 -6055 .

9. Aebi H, Suter H. Protec ve func on of reduced glutathione against the effect of pro-oxida ve substances and of irradia on in the red cell. Glutathione. Georg Thieme; Stu gart: 1974; 192-9.

10. Ahmad R, Tripathi A K, Tripathi P, Singh R, Singh S, Singh R K. "Studies on lipid peroxidation and non-enzymatic antioxidant status as indices of oxidative stress in patients with chronic myeloid leukemia". Singapore Med J; 51(2) : 110, 2010.

11. Beers RF, Sizer IW. A spectrophotometric method for measuring the breakdown of hydrogen peroxides by catalase. $\mathrm{J}$ BiolChem; 1952; 195: 133-140.

12. Breus, T.K., Cornelissen, G., Halberg, F. and levitin, A.D.,"Temporal associations of life with solar and geophysical activity" Ann. Geophys; 13:1211 - 1222, 1995.

13. Breus, T.K.,Halberg, F. and Cornelissen, G., "Influence of solar activity on the physiological rhythms of biological system". Biofizika (Russian); 40(4):737 748 1995. Bunning, E., "The physiological clock; Circadian rhythms and biological chronometery. $3^{\text {rd }}$ edn. Springer, Berlin, Heidelberg, New York, 1973.

14. Bunning E. "The physiological clock; endogenesis; diurnal rhythms and biological chronometry". Academic, New York, 1964.

15. Conroy, R.T.W.L and Mills, J.N. "Human circadian rhythms". Churchill,London 1970.

16. Chronomics and Chronobiology in health and disease. Singh RK. Indian Journal of clinical Biochemistry. 24(4) 319-323, 2009.

17. Das SK, Nayak P, Vasudevan DM. Biochemical Markers for Alcohol Consumption. Ind J ClinBiochem. 2003; 18(2): 111-118.

18. Das SK, Vasudevan DM. Monitoring oxidative stress in patients with nonalcoholic and alcoholic liver diseases. Ind J ClinBiochem. 2005; 20(2). (In Press)

19. Frienhel, N., Aky, R.A, Singer, D.L, Cohen, A.K.(1985). Alcohol hypoglycemia IV. Current concepts of its pathogenesis. Diabetes 4, 350-361.

20. Goldberg, M.D.; and Spooner, J.R.. In: Methods of Enzymatic Analysis (ed. Bergmayer), Vol. III, $3^{\text {rd }}$ edn. Academic Press, Inc., Florida, 1983; pp. 258-265.

21. Grant BF, Harford TC. Epidemiology of alcoholic liver disease. Semin Liver Disease 1988; 8:12-25. Gupta S, Pandey R, Katyal R, Agarwal HK, Agarwal SK. 
Lipid peroxide and antioxidant status in alcoholic liver disease. Ind J Clin Biochem 2005; 20(1): 67-71.

22. Halberg, F. Lornelissen, G.,Bakken, E., "care giving merged with chronobiologic outcome assessment, research and education in health maintenance organization”. Prog. Clin Biol. Res; 3418: 491 - 549, 1990.

23. Halberg, F., “Chronobiology”. Ann. Rev Physiol; 31; 675 - 725; 1969.

24. Halliwell; B,. Antioxidants in human health and disease". Annu. Rev. Nutr; 16: $33-50,1996$.

25. Halliwell, B.,Gutteridge, J.M.C, "Free radicals in biology and medicine" $3^{\text {rd }}$ ed. Oxford kingdom, Oxford University press, 1999.

26. Harman, D., "Role of free radicals in aging and disease". Annals of New York Academy of Sciences; 673: 126 - 141; 1992.

27. Hans, E. and Halberg, F., "The Circadian time structure". NATO Adv. Study Inst [D]: $47-94,1980$.

28. Halberg, F. Quo vadis basic and clinical chronobiology: promise for health maintenance. Am J Anat; 168:543-94, 1983.

29. Haus E, Touitou Y. "Chronobiology in laboratory medicine". In: Touitou Y, Haus E, editors. Biologic rhythms in clinical and laboratory medicine. Springer-Verlag; Berlin, Heidelberg, New York: pp. 673708, 1992.

30. Halberg, F. "Implications of biologic rhythms for clinical practice". HospPract.; 12:139-49, 1977.

31. Hirnwich, H.E., Nahum, L.H., Pakieten, N., Fazekas, J.F., DU Bots, H. (1982). Effects of alcohol on metabolism. Am.J.Physiol. 101, 57-68.

32. Irshad M, Chaudhuri PS. "Oxidantantioxidant system: role and significance in human body". Indian J ExpBiol; 40:1233-9, 2002.

33. Jose C. Fernández-Checa, Ph.D., Neil Kaplowitz, M.D., Anna Colell, and Carmen García-Ruiz, Ph.D. Oxidative Stress and Alcoholic Liver Disease: RESEARCH UPDATE.

34. Kolanjiappan, k. Manoharan, S. and Kayalvizhi, M. (2002).Measurement of erythrocyte lipids, lipid peroxidation, antioxidants and osmotic fragility in cervical cancer patients. Clin. Chin. Acta. 326, 143-149.

35. Langseth, L, "Oxidants; antioxidants and disease prevention". Belgium, International Life Science Institute, 1996.

36. Liber CS. Alcohol and liver: metabolism of alcohol and its role in hepatic and extrahepatic diseases. Mt Sinai J Med 2000; 67 (1): 84-94.

37. Liber CS. Biochemical and molecular basis of alcohol induced injury to liver and other tissues. N Eng J Med 1988; 319:1639-1650.

38. Lieber CS. Ethanol metabolism, cirrhosis and alcoholism. Clin. Chim. Acta1997; 257(1): $59-84$.

39. McCord. J.M and Fridovich, I., "Superoxide dismutase: an enzyme functions for erythrocuprin". J. Biolchem, 24: 6049 - 6055, 1969.

40. Natelson. S., "Techniques of clinical chemistry". $3^{\text {rd }}$ ed., Publisher charles, C., Thomas, USA, 286, 751 and 162, 1971.

41. OhKawa, H., Ohishi, N. and Yagi, K., "Assay for lipid peroxidase in animal tissues by thiabarbituric reaction". Annal Biochemi; 95: 151 - 157, 1979.

42. Pagila, D.E Valentine, W.N., "Studies on quantitative and qualitative characterization of erythrocyte glutathione peroxidase" J Lab clinMed; 2; 158 - 169, 1967.

43. R. Singh, R. K. Singh, R. K. Singh, A. K. Tripathi, G. Cornélissen, O. Schwartzkopff, K. Otsuka, and F. Halberg. 
Chronomics of circulating plasma lipid peroxides and anti-oxidant enzymes and other related molecules in cirrhosis of liver. Biomed Pharmacother. 2005 October; 59(Suppl 1): S229-S235.

44. Sie H: Oxidative stress: from basic research to clinical application. Am J Med 1991; 9: 31-38.

45. Singh R, Singh RK, Mahdi AA, et al. "Circadian periodicity of plasma lipid peroxides and other anti-oxidants as putative markers in gynecological malignancies”. In Vivo; 17:593-600, 2003. 